\title{
Physicochemical, Chemical and Enzymatic Properties of a Crystalline Yeast Cell Lytic Enzyme from a Rhizopus $\mathrm{Mold}^{\dagger}$
}

\author{
Shimpei Yamamoto, Reisuke Kobayashi* and Susumu Nagasaki \\ Department of Agricultural Chemistry, Faculty of Agriculture, Kochi University, Nankoku, Kochi \\ *Chemical Research Laboratory, Kumiai Chemical Industry Co., Ltd., Shimizu, Shizuoka
}

Received January 24, 1974

\begin{abstract}
A kind of $\beta-1,3$-glucanase which degrades the cells of living yeasts has been crystallized from a culture filtrate of a strain resembling Rhizopus chinensis and has been studied from physicochemical, chemical and enzymological perspectives. The physicochemical and chemical peoperties revealed by the studies are as follows: molecular weight, 22,000 24,000; molecular extinction coefficient, $2.335 \times 10^{4} \mathrm{M}^{-1} \mathrm{~cm}^{-1} ; s_{20, \mathrm{w}}^{\circ}, 2.47 \mathrm{~S} ; D_{20, \mathrm{w}}^{\circ}, 9.46 \times 10^{-7}$; isoelectric point, pH 5.2; Stokes radius, $23 \AA$; intrinsic viscosity, $0.0336 \mathrm{dl.g}^{-1}$; axial ratio, 3.9; amino acid composition, 205 residues of 17 amino acids; $\mathrm{N}$-terminal amino acid, valine; $\mathrm{C}$-terminal amino acid sequence, -Asp-Thr-Ala-Gly-Ser; optimum pH 5.5; optimum temperature, $40^{\circ} \mathrm{C}$; stability stable at $\mathrm{pH} 4.5 \sim 6.0$ or below $80^{\circ} \mathrm{C}$. Though the exact bond split by the enzyme could not be identified, within the scope of this paper the enzyme's mode of action suggested it to be either a "more random" or a "debranching" type of $\beta$-1,3-glucan-glucanohydrolase.
\end{abstract}

A number of papers showing significant advances in the understanding of enzymic disruption of the cells of living yeasts (or enzymic formation of the protoplasts) have appeared, ${ }^{1 \sim 41)}$ but only a few researchers ${ }^{32 \sim 41 \text { 1 }}$ have succeeded in attempts to purify the enzyme responsible for such action. The authors have crystallized $\beta$-1,3-glucanase having such action from a culture filtrate of a Rhizopus $\mathrm{sp}^{35,36)}$ and a species of Fungi Imperfecti ${ }^{40,41)}$ respectively. Independently, Mada et al. ${ }^{34}$ Kitamura et al. ${ }^{33,37)}$ and Doi et al..$^{32,39)}$ also have isolated $\beta$-1,3-glucanases, which degraded living yeast cells, from culture filtrates of Irpex lacteus $\mathrm{M}$ and Arthrobacter luteus.

It has been recognized by some research$\operatorname{ers}^{19,23)}$ that general $\beta$-1,3-glucanase evidences little activity against the cells of living yeast. In this respect, the above mentioned $\beta$-1,3-glucanases seems to have unique properties when

+ Studies on Fungal Enzymes Active in Hydrolysing Yeast Cell Wall, Part III. Part II; see Reference 41). This work was supported partly by the grant, No.856056 from the Ministry of Education, Japanese Government. A part of this report was presented at the $272 \mathrm{nd}$ Meeting of the Kansai branch of the Agr. Chem. Soc. of Japan, held at Kyoto, May 22, 1971 and at the annual Meeting of the Soc. of Fermen. Technol., Japan, held at Osaka, November $17 \sim 20,1971$. compared with the general $\beta$-1,3-glucanase wide spread in microorganisms. However, with the exception of the Fungi Imperfecti ${ }^{40,41)}$ and Arthrobacter $^{39)}$ glucanases, the enzymatic and physicochemical properties of those glucanases have not yet been fully elucidated.

The present paper describes physicochemical, chemical and enzymic properties of the Rhizopus glucanase, of which purification, crystallization and substrate specificity have been tentatively reported in a previous paper. ${ }^{36)}$

\section{MATERIALS AND METHODS}

Microorganism. The strain described in a previous paper $^{36 !}$ served for production of the yeast cell-lytic enzyme. The organism was readily recognized by its characteristic rhizoid formation to belong to the genus Rhizopus. The morphological, cultural and physiological characteristics of the organism were systematically investigated according to lizuka's classification method $^{42)}$ of the genus Rhizopus.

Production of the lytic enzyme. After extensive investigation the following conditions were selected for the production of the lytic enzyme: medium: $5 \%$ baker's yeast and $0.1 \% \mathrm{NaH}_{2} \mathrm{PO}_{4} \cdot 2 \mathrm{H}_{2} \mathrm{O}$, pH 6.0 ; culture conditions: $30^{\circ} \mathrm{C}$ for $72 \mathrm{hr}$ with shaking.

Enzymes used. Purification and crystallization of the sample enzyme were conducted as described in a 
previous paper ${ }^{36)}$ : crystals of the enzyme have also been shown in the same paper. To compare the mode of action of the sample enzyme to other $\beta$-glucanases, endo $\beta$-1,3-glucanase and endo $\beta$-1,6-glucanase were prepared from the same organism. Production, purification procedures and properties of those enzymes will be reported later.

Assay of enzymes. Assay of the lytic enzyme involved a measurement by the phenol-sulfuric acid method or Somogyi-Nelson method of the liberation of reducing sugar from yeast glucan or laminarin or a measurement of turbidity change due to the disruption of living yeast cells. Details of the procedures have been described in a previous paper. ${ }^{43}$ Assay of $\beta-1,3-$ glucanase and $\beta$-1,6-glucanase involved a measurement by the 3,5-dinitrosalicylic acid (DNSA) method of the liberation of reducing sugar from laminarin and luteose respectively.

Ultracentrifugation analysis. Sedimentation velocity, sedimentation equilibrium, and diffusion experiments were performed in a Hitachi Model 282 analytical ultracentrifuge equipped with Schlieren optics, Rayleigh interference optics and photoelectric scanner. Prior to centrifugation an enzyme solution was dialyzed against $\mathrm{m} / 100$ acetate buffer, $\mathrm{pH} 5.0$, containing $\mathrm{M} / 10$ potassium chloride for $72 \mathrm{hr}$ at $5^{\circ} \mathrm{C}$ with several changes of the buffer. The final dialyzate was used as a reference solution for all runs. All measurements were made at $20^{\circ} \mathrm{C}$.

Disc electrophoresis. Disc electrophoresis on polyacrilamide gel was performed according to the procedures of Davis, ${ }^{44}$ Ornstein ${ }^{44}$ or Weber and Osborn. ${ }^{48}$

Viscosity measurements. Viscosity was measured in a micro Ubbelohde type capillary viscometer with flow times for water of $150 \mathrm{sec}$ at $20.00^{\circ} \pm 0.01^{\circ} \mathrm{C}$. All measurements were made at $20.00^{\circ} \pm 0.01^{\circ} \mathrm{C}$.

Amino acid analysis. Quantitative analysis of amino acids of the enzyme protein was achieved by the conventional ion exchange chromatography using Yanagimoto amino acid analyzer Model LC-2 (Yanagimoto Co., Ltd., Kyoto) equipped with a $15 \mathrm{~cm}$ and a $150 \mathrm{~cm}$ column of Amberlite CG 120 Type 3. In addition to this, the following methods were employed for respective amino acids; the method of Scoffen ${ }^{47}$ ) was used for the assay of tryptophan, the method of Goodwin and Morton ${ }^{48}$. was used for the assay of tyrosine and tryptophan, cysteine was determined as cysteic acid and Scarboxymethylcysteine according to the method of Crestifield et al..$^{49}$ and Moore et al. ${ }^{54}$ respectively, and methionine was estimated from a number of component peptides which separated in a acrylamide gel column with disc electrophoresis after the cyanogen bromide treatment described by Steers et al. ${ }^{51 !}$
Analyses for $N$-terminal amino acid and C-terminal amino acid. N-Terminal amino acid of the enzyme was determined by the dinitrophenyl (DNP) method of Sanger, ${ }^{53}$ ! improved phenylthiohydantoin (PTH) method of Erikson and Sjöquist ${ }^{54 !}$ and Dansyl (DNS) method of Hartley. ${ }^{55)}$ The dinitrophenylation was done on a native enzyme, performate-oxidized enzyme, S-carboxymethylated enzyme, and sodium borohydridereduced and S-carboxymethylated enzyme. Quantitative estimation of the DNP-amino acid was carried out following the method described by Levy, ${ }^{56}$ and identification of the PTH-amino acid and the DNS-amino acid were performed by the paper chromatography of Sjöquist ${ }^{57)}$ and Boulton and Bush ${ }^{581}$ respectively.

C-Terminal amino acid was determined by the hydrazinolysis method of Akabori, ${ }^{591}$ acid-catalyzed hydrazinolysis method ${ }^{60}$ and -carboxypeptidase A method.61; Amino acids released from the sample protein by the action of the carboxypeptidase $\mathrm{A}$ were analyzed with the amino acid autoanalyzer.

\section{RESULTS}

\section{Physicochemical properties}

Absorption spectrum. The absorption spectrum of the crystalline lytic enzyme was taken by a Shimadzu recording spectrophotometer Model MPS-50L (Fig. 1). In the investigated wave length range the enzyme exhibited maximum absorption at $278 \mathrm{~nm}$. Assuming the molecular weight of the enzyme to be 23,000 ,

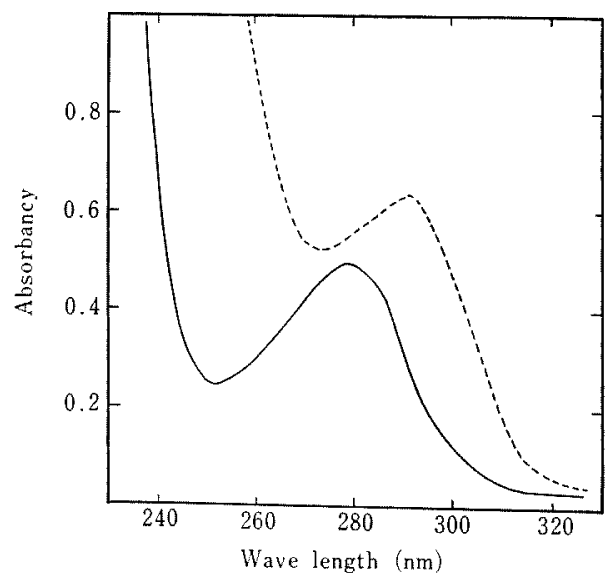

Fig. 1. Ultraviolet Absorption Spectra of the Crystalline Rhizopus Glucanase.

The enzyme protein, $4 \mathrm{mg}$, was dissolved in $10 \mathrm{ml}$ of $\mathrm{M} / 100$ acetate buffer, $\mathrm{pH} 7.0$, or of $\mathrm{N} / 10 \mathrm{NaOH}$, and the absorption spectrum of the solution was recorded on a Shimadzu recording spectrophotometer model MPS 50-L. Solid line, spectrum in buffer; dotted line, spectrum in $\mathrm{NaOH}$ solution. 
the number of tryptophan and tyrosine residues per mole of enzyme were estimated from the curve to be 2 and 9 respectively, and the molecular extinction coefficient $(\varepsilon)$ was calculated to be $2.335 \times 10^{4} \mathrm{M}^{-1} \mathrm{~cm}^{-1}$

Ultracentrifugation analysis. (1) The sedimentation pattern of the enzyme is shown in Fig. 2. The boundary of the enzyme moved as a single symmetrical peak, as was expected for homogeneous materials.

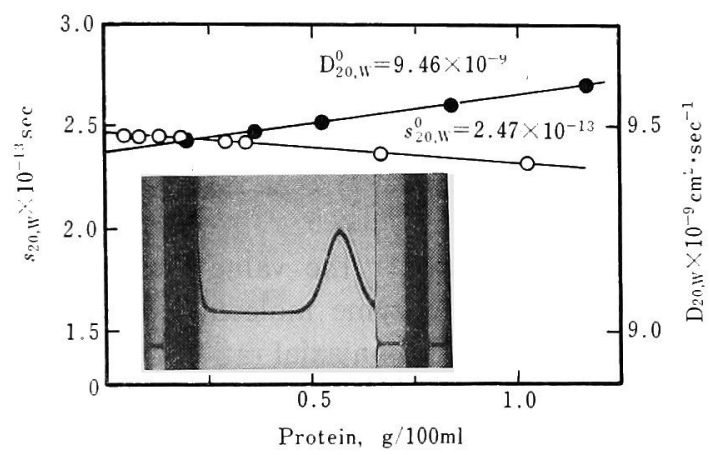

FIG. 2. Plots of $s_{20, \mathrm{w}}$ and $D_{20, \mathrm{w}}$ vs. Concentration of Protein, and Sedimentation Pattern of the Crystalline Rhizopus Glucanase.

The experimental conditions are given in the text. The photograph was taken (protein conc., $3.83 \mathrm{mg} / \mathrm{ml}$ ) $88 \mathrm{~min}$ after the rotor reached a speed of $56,000 \mathrm{rpm}$. Sedimentation is proceeding from right to left. $\mathrm{O}-\mathrm{O}$, sedimentation velocity; - diffusion coefficient.

(2) The sedimentation coefficient of the enzyme was measured at various protein concentrations. There appeared to be a slight concentration dependence in the values over the protein concentration range of 0.35 to 10.18 $\mathrm{mg} / \mathrm{ml}$ studied (Fig. 2). The concentration dependence is represented by the equation

$$
s_{20, \mathrm{w}}=s_{20, \mathrm{w}}^{0}(1-0.0445 \mathrm{C})
$$

With the extrapolation of $s_{20, \mathrm{w}}$ to zero protein concentration the value of 2.47 was determined for $s_{20 \text {, w }}^{0}$.

(3) The diffusion coefficient of the enzyme was calculated, using the maximum ordinatearea method, from the Schlieren patterns of the enzyme solutions. As is shown in Fig. 2, the diffusion coefficient $\left(D_{20, \mathrm{w}}\right)$ increased linear- ly with increasing concentration. On extrapolating the straight line to zero protein concentration the value of 9.46 was obtained for $D_{20, w}^{0}$. Rate constant of the line was calculated from the slope to be $D_{20, \mathrm{w}}^{0} \times 0.0132$, and therefore the equation

$$
D_{20, \mathrm{w}}=D_{20, \mathrm{w}}^{0}(1+0.0132 \mathrm{C})
$$

represents empirical value for $D_{20, w}$.

(4) The enzyme was subjected to equilibrium ultracentrifugation in aqueous and heavy water buffers according to the method described by Edelstein and Schachman ${ }^{62}$ Figure 3 shows the plot of the natural logarithm of

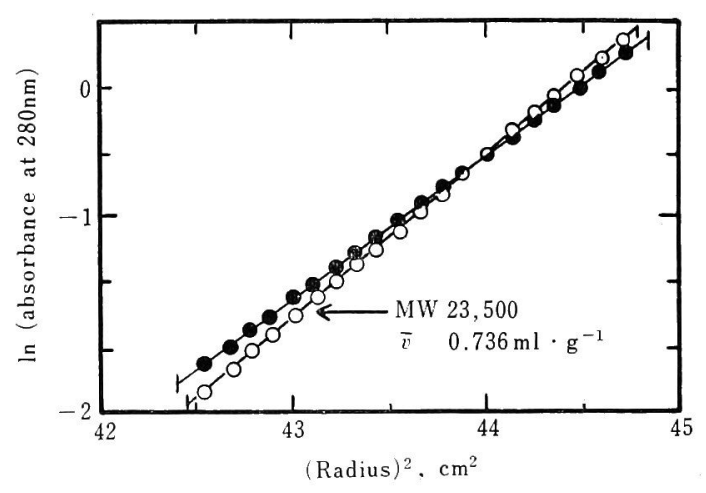

FIG. 3. Simultaneous Determination of Partial Specific Volume and Molecular Weight of the Enzyme.

The experiment was performed according to the method described by Edelstein and Schachman. ${ }^{621}$ For this experiment the speed was $20,000 \mathrm{rpm}$, multichannel cell was used, and protein concentration was $30 \mu \mathrm{g} / 0.1 \mathrm{ml}$. $\bigcirc-\mathrm{O}$, sedimentation equilibrium in $\mathrm{H}_{2} \mathrm{O}$;- sedimentation equilibrium in $\mathrm{D}_{2} \mathrm{O}$.

absorbance at $280 \mathrm{~nm}$ against the radius square. The graphs are both linear over the entire range, with the slope in $\mathrm{D}_{2} \mathrm{O}$ equal to 0.7894 that of the slope in $\mathrm{H}_{2} \mathrm{O}$. The partial specific volume of the enzyme was calculated to be 0.736 according to the method of Edelstein and Schachman, and it checks very well with the value calculated from the amino acid composition of the enzyme protein according to the method of McMeekin and Marshall. ${ }^{63)}$

Determination of molecular weight. (1) The molecular weight of the enzyme was calculated to be 23,000 by substituting the empirical values 
for $D_{20 \text {,w }}^{0}$ and $s_{20, w}^{0}$ in the Svedberg equation.

(2) The molecular weight of the enzyme was determined to be 23,400 according to the sedimentation equilibrium method of Van Hold and Baldwin. ${ }^{64)}$ This value is in essential agreement with that obtained above.

(3) On comparing the mobility of the enzyme on polyacrilamide gel containing sodium dodecyl sulfate with that of reference proteins, a molecular weight of 22,000 was estimated for the denatured enzyme.

Isoelectric point. The isoelectric point of the enzyme was determined to be around $\mathrm{pH}$ 5.2 by paper electrophoresis using Miller and Gorder's buffer ${ }^{65)}$ and Toyo Roshi No. 51 filter paper as supporting material.

Stokes radius. The Stokes radius of the enzyme was obtained by molecular sieve chromatography using Sephadex G-100 according to the procedures of Acker. ${ }^{66)}$ The pore radius of the column was determined with catalase, ovalbumin, chymotrypsinogen $\mathrm{A}$, myoglobin and cytochrome $\mathrm{C}$ as standards. On the basis of the elution characteristics on the calibrated column, Stokes radius of the enzyme was calculated to be $23 \AA$, corresponding to a molecular weight of 24,000 . On substituting this value for the Stokes radius in the StokesEinstein equation, the diffusion coefficient of the enzyme was calculated to be $9.01 \times 10^{-7}$ $\mathrm{cm}^{-2} \mathrm{sec}^{-1}$ This value is very similar to that obtained above with the method of Ehrenberg.

Intrinsic viscosity and molecular shape. To obtain information on molecular shape, viscosity studies were conducted with an enzyme solution in $\mathrm{m} / 100$ acetate buffer, $\mathrm{pH} 5.0$, containing $\mathrm{M} / 10$ potassium chloride (Fig. 4). Reduced viscosity, $\eta_{\mathrm{sp}} / \mathrm{C}$, was plotted against protein concentration, $\mathrm{C}$. The data show that the reduced viscosity is independent of the enzyme concentration, and a value of $3.36 \mathrm{ml} / \mathrm{g}$ was obtained for the intrinsic viscosity. On substituting the observed values, $0.0336,0.736$ and 23,000 respectively, for $\eta, \bar{v}$ and $\mathrm{M}$ in the Scheraga-Manderkern equation, ${ }^{67)}$ a value, $2.25 \times 10^{6}$, was obtained for $\beta$. According to

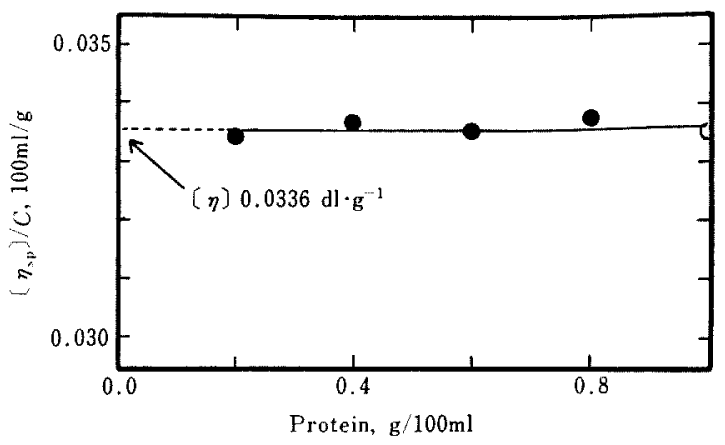

FIG. 4. Plots of the Reduced Viscosity vs. Concentration of Protein.

Enzyme solution of various concentrations in $M / 100$ acetate buffer, $\mathrm{pH} 5.0$, containing $\mathrm{M} / 100 \mathrm{KCl}$ was subjected to viscosity measurement in a Ubbelohde type capillary viscometer. Further details are described in the text.

the Scheraga's data, ${ }^{68}$ the value means that the shape of the enzyme molecule may be a prolate spheroid with an axial ratio of 5 , which is roughly in agreement with the value, 3.93, calculated from $[\eta]$ and $\bar{v}$ taking the KuhnKuhn equation. ${ }^{69}$

\section{Chemical properties}

Amino acid composition. Table I gives the amino acid composition of the enzyme protein. From the data the molecular weight and the partial specific volume of the enzyme were calculated to be 22,400 and 0.736 respectively. The values are consistent with those obtained with other methods. After being separated into component peptides by cyanogen bromide treatment, a value of 3 for the methionine residue of the enzyme was further confirmed by disc gel electrophoresis (Fig. 5).

Subunit structure. In order to break it down into its component peptides the enzyme protein was subjected to gel electrophoresis in the presence of sodium dodecyl sulfate and $8 \mathrm{M}$ urea, respectively. In either case enzyme protein migrated in a single band and was shown to be composed of a single polypeptide.

$N$-Terminal amino acid of the enzyme protein. On hydrolysis of the dinitrophenylates of native enzyme, performate-oxidized enzyme, $S$. 
Table I. Amino Acid Composition of THE ENZYME ProteIN

\begin{tabular}{lc}
\hline \multicolumn{1}{c}{ Amino acid } & $\begin{array}{c}\text { Number of } / \text { Mole } \\
\text { residue }\end{array}$ \\
protein
\end{tabular}

carboxymethylated enzyme, and reduced and S-carboxymethylated enzyme, $1.10,0.82,1.21$ and 0.63 mole of DNP-valines were found per mole of respective enzyme preparations. The $\mathrm{N}$-terminal residue valine was further confirmed by the phenylthiohydantoin method and Dansyl method.

C-Terminal amino acid of the enzyme protein. On hydrazinolysis of the enzyme, about 0.68 mole of serine was released per mole of enzyme along with small amounts of glycine and alanine. On hydrazinolysis in the presence of hydrazine sulfate as catalyst, 0.77 mole of serine was released per mole of enzyme. These results support the data, from which -Asp-ThrAla-Gly-Ser was estimated for the C-terminal amino acid sequence, obtained with the carboxipeptidase A method (Fig. 6).

\section{Enzymatic properties}

Effect of $\mathrm{pH}$ on enzyme activity. Enzyme activity was measured at various $\mathrm{pH}$ from 2.0

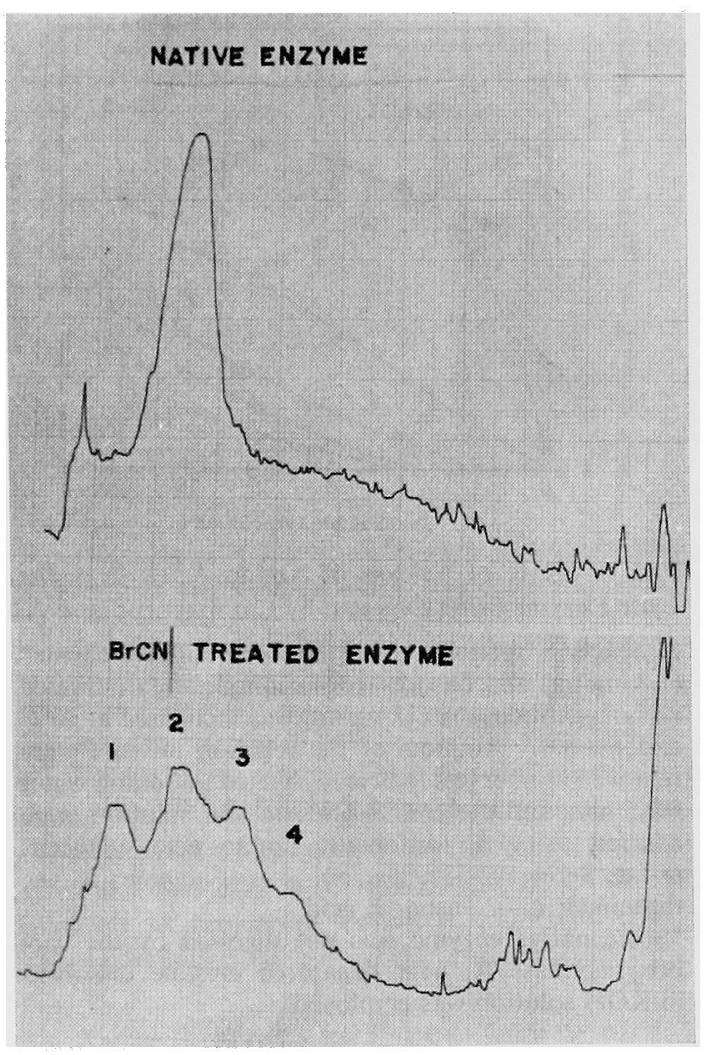

FIG. 5. Scanning Densitogram of the Acrilamide Gel Columns on Which Native or BrCN-Treated Enzyme had been Electrophoretized.

The $\mathrm{BrCN}$ treatment was performed on $13.7 \mathrm{mg}$ of the enzyme according to the method of Steers et al..$^{51\}}$ Electrophoresis was carried out following the method of Davis ${ }^{44}$ employing approximately $60 \mu \mathrm{g}$ (native eneyme) or $80 \mu \mathrm{g}$ (BrCN-treated enzyme) of enzyme, and the distribution of protein in the stained gels was recorded with the aid of a densitometer, Toyo densitorol DM-6, at a wave-length of $622 \mathrm{~nm}$ and with a slit of $0.22 \mathrm{~mm}$.

to 8.0. As is shown in Fig. 7, maximum activity was obtained at around $\mathrm{pH} 5.5$.

Effect of temperature on the enzyme activity. Enzyme activity was measured at various temperatures from $20^{\circ} \mathrm{C}$ to $60^{\circ} \mathrm{C}$, as shown in Fig. 7 , maximum activity being obtained at about $40^{\circ} \mathrm{C}$.

Effect of $p H$ on the stability of the enzyme. Enzyme solutions adjusted to various $\mathrm{pH}$ were treated at $45^{\circ} \mathrm{C}$ for $10 \mathrm{~min}$ and subsequently assayed for remaining activity under the stan- 


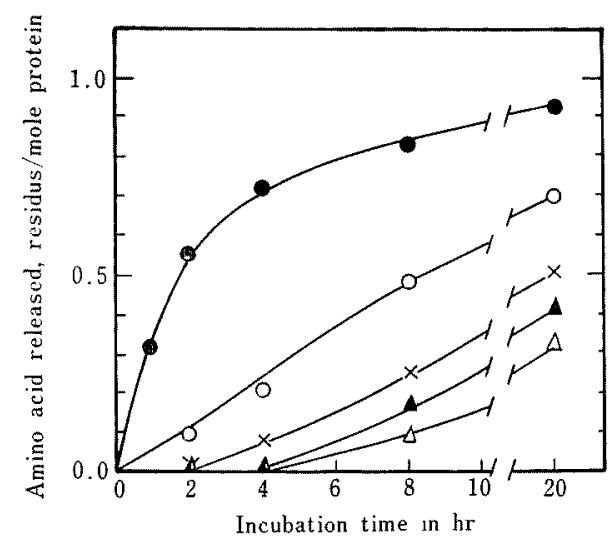

Fig. 6. Rate of Release of Amino Acids from the Lytic Enzyme being Digested by Carboxypeptidase A.

A reaction mixture containing crystalline enzyme* $(1.8 \mathrm{mg} / \mathrm{ml})$ and diisopropylphosphofluoridate-treated carboxypeptidase A (22 $\mu \mathrm{g} / \mathrm{ml})$ was incubated at $30^{\circ} \mathrm{C}$ and $\mathrm{pH}$ 8.0. Aliquots of the reaction mixture were removed at intervals indicated, heated in boiling water for $5 \mathrm{~min}$, and the amino acids in the solution were assayed using an automatic amino acid analyzer.

$-\bullet$ Serine; $0-0$, glycine; $x-x$, alanine; $\mathbf{\Lambda}-\mathbf{\Lambda}$, threonine; $\triangle-\triangle$, aspartic acid.

*Since native enzyme was not digested by the carboxypeptidase $\mathrm{A}$, heat denatured enzyme dissolved in $\mathrm{KOH}$ solution was employed.

dard assay conditions. As is shown in Fig. 7, the enzyme was stable at $\mathrm{pH} 4.5 \sim 6.0$.

Effect of temperature on the stability of the enzyme. As is shown in Fig. 7, the enzyme retained $70 \%$ of its original activity even after treatment at $80^{\circ} \mathrm{C}$. When stored at $3^{\circ} \mathrm{C}$ the enzyme retained $97 \%$ of its activity even after $158 \mathrm{hr}$, whereas at $35^{\circ} \mathrm{C}$ its activity dropped to $80 \%$ of its initial activity after $24 \mathrm{hr}$.

Action on yeast glucan. After digestion of yeast glucan by the enzyme, turbidity change and release of glucose, carbohydrates, and reducing sugars were measured. As is shown in Fig. 8, the turbidity of a glucan suspension lowered rapidly with the release of carbohydrates and comparatively small amount of reducing sugar, but glucose was scarcely released during the digestion. The results of Sephadex G-15 column chromatography of the hydrolysis products are shown in Fig. 9. A large molecule fraction separated from the reaction mixtures at an initial stage of the diges-

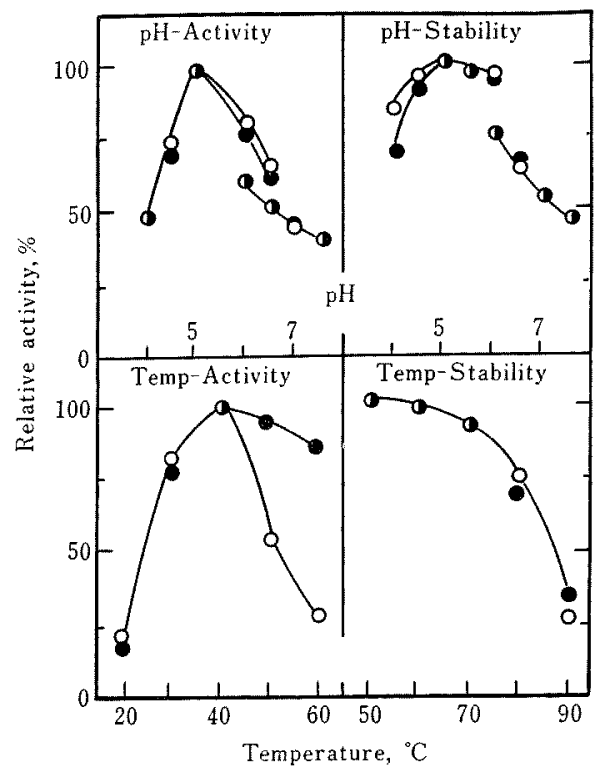

FIG. 7. Effect of $\mathrm{pH}$ and Temperature on the Enzyme Activity.

In the temperature-stability experiment, enzyme solutions in $\mathrm{M} / 100$ acetate buffer, $\mathrm{pH} 5.0$, were respectively heated for $10 \mathrm{~min}$ at various temperatures indicated and the remaining activities were assayed under the standard assay conditions. Further experimental conditions are described in the text. $\bigcirc-0$, lytic activity on living yeast cells; - - , yeast glucan depolymerization activity; $\mathrm{pH} 4 \sim 6$, acetate buffer; $\mathrm{pH}$ 6 7.5, phosphate buffer.

tion was demonstrated by ultracentrifugation analysis to be composed primarily of a polysaccharide with a molecular weight of 7,500, $\overline{\mathrm{DP}} 42$ (Fig. 10). The polysaccharide had been digested by the crystalline Rhizopus glucanase, $\beta$-1,3-glucanase and $\beta$-1,6-glucanase respectively with oligosaccharides as products, as demonstrated in Fig. 11.

Reduction by sodium borohydride and oxidation by periodate of yeast glucan did not affect enzyme activity, whereas $\beta$-1,3-glucanase treatment of yeast glucan affected its activity, as is shown in Table II.

Action on laminarin. The lytic enzyme differs clearly from general endo $\beta$-1,3-glucanase in its action on laminarin; that is, endo $\beta$-1,3-glucanase obtained from the same organism decomposed laminarin almost completely, with $G_{1}$ to $G_{3}$ oligosaccharides as products, 


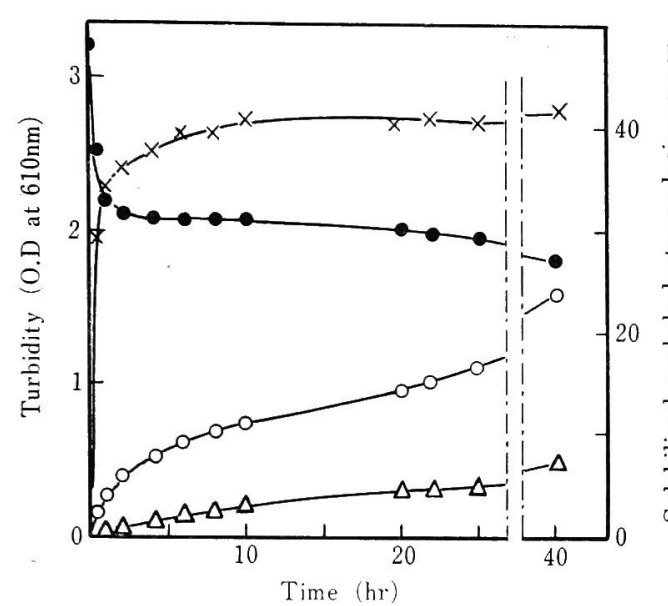

FIG. 8. Action of the Crystalline Enzyme on Yeast Glucan as Revealed by Turbidity Change and Carbohydrate Release.

A reaction mixture containing $500 \mathrm{mg}$ of yeast glucan and $0.5 \mathrm{mg}$ of the enzyme in $100 \mathrm{ml}$ of $\mathrm{M} / 20$ acetate buffer, $\mathrm{pH} 5.0$, was incubated at $40^{\circ} \mathrm{C}$ with gentle shaking, and at indicated times an aliquote of the mixture was withdrawn for the measurements. Assay methods were as follows: glucose, the glucose oxidase method; released carbohydrate, the phenol- $\mathrm{H}_{2} \mathrm{SO}_{4}$ method; reducing sugar, the Somogyi-Nelson method. - - Turbidity; $\times-\times$, released carbohydrate; $\bigcirc-0$, reducing sugar; $\Delta-\Delta$, glucose.

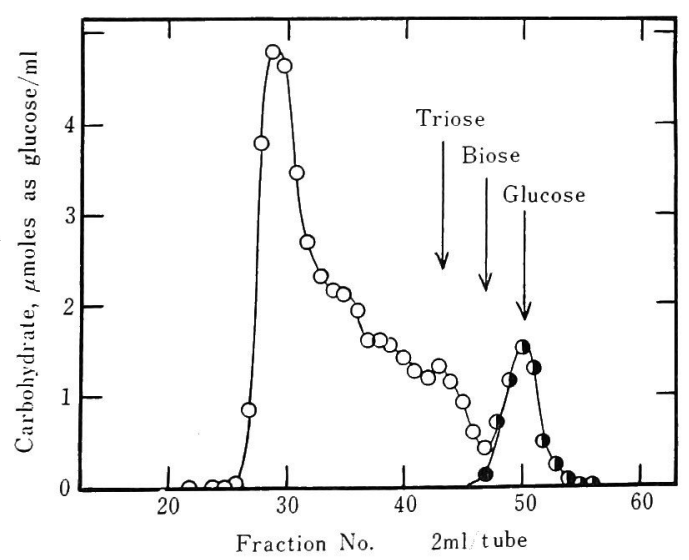

FIG. 9. Separation on Sephadex G-15 of Products of Digestion of Yeast Glucan by the Crystalline Rhizopus Glucanase.

Sample was obtained from the experiment of Fig. 8. After $40 \mathrm{hr}$ incubation, the reaction mixture was centrifuged to eliminate insoluble matter and concentrated. One $\mathrm{ml}$ of the concentrated solution was applied to a Sephadex G-15 column, $15 \times 800 \mathrm{~mm}$. Flow rate was $1 \mathrm{ml} / 5 \mathrm{~min}$ and $2 \mathrm{ml}$ of eluate were collected in each tube. Carbohydrate was assayed by the phenol- $\mathrm{H}_{2} \mathrm{SO}_{4}$ method, $(\mathrm{O}-\mathrm{O})$; glucose was assayed by the glucose oxidase method, (-).

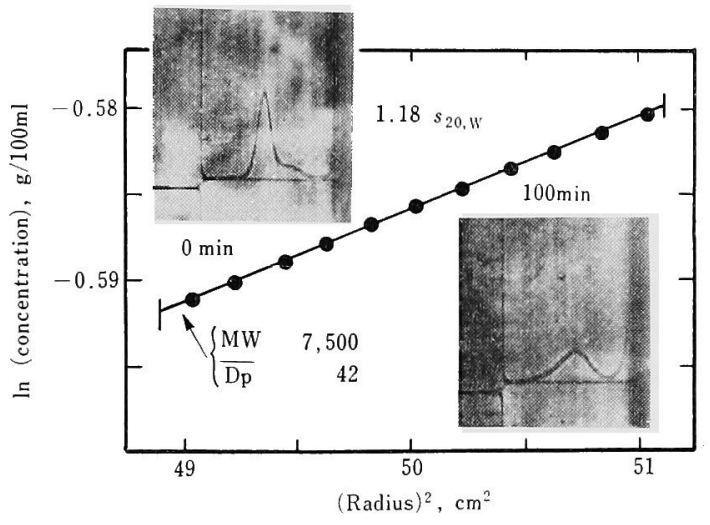

FIG. 10. Determination of Molecular Weight and Sedimentation Coefficient of an Oligoglucan Solubilized by the Enzyme from Yeast Glucan.

A reaction mixture, of which composition was the same as that described in the legend to Fig. 8, was incubated for $20 \mathrm{~min}$ at $40^{\circ} \mathrm{C}$, heated for $5 \mathrm{~min}$, centrifuged $(10,000 \mathrm{rpm}, 10 \mathrm{~min})$, and the supernatant was concentrated, dialyzed vs. $0.1 \mathrm{M} \mathrm{KCl}$ and used for the experiment. Determination of $s_{20, \mathrm{w}}^{0} ; 4 \%$ sample, synthetic boundary cell, $60,000 \mathrm{rpm}, 20^{\circ} \mathrm{C}$ : determination of molecular weight; $0.1,0.2$ and $0.4 \%$ sample, multichannel cell, $20,000 \mathrm{rpm}, 20 \mathrm{hr}, 20^{\circ} \mathrm{C}$.

\section{Table II. Effect on Enzyme Activity of Chemical and Enzymic Modification on Yeast Glucan}

The $\beta$-1,3- and the $\beta$-1,6-glucanase treated yeast glucan were prepared from the insoluble residues of yeast glucan which was subjected to the digestion with respective glucanases. The other glucans were prepared following the procedures described by Misaki et $a{ }^{711}$ For the experimental conditions, see the previous paper. ${ }^{40)}$

\begin{tabular}{lc}
\hline \multicolumn{1}{c}{ Substrate } & $\begin{array}{c}\text { Relative activity } \\
(\%)\end{array}$ \\
\hline Native glucan & 100 \\
$\mathrm{NaBH}_{4}$-Reduced glucan & 102 \\
$\mathrm{IO}_{4}$-Oxidized, $\mathrm{NaBH}_{4}-$ & 101 \\
$\quad$ reduced and mild acid- & \\
$\quad$ hydrolysed glucan & 22 \\
$\beta-1,3-$ Glucanase treated glucan & \\
$\beta-1,6-$ Glucanase treated glucan & 78 \\
\hline
\end{tabular}

while the lytic enzyme did not produce oligosaccharide from laminarin in a readily recognizable amount and hence the gel filtration of laminarin treated with the lytic enzyme on a Sephadex G-15 column showed the same elution pattern as that of control laminarin. 


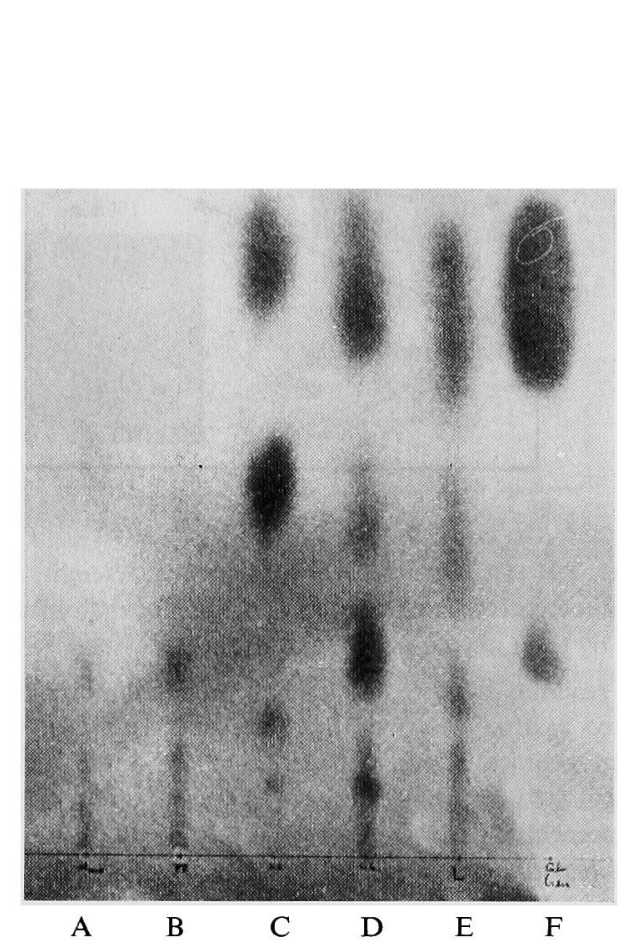

FIG. 11. Paper Chromatogram of the Digests of Enzymatically Solubilized Polysaccharide.

The polysaccharide was obtained by precipitation with alcohol from the reaction mixture described in the legend to Fig. 10. Reaction mixtures containing $20 \mathrm{mg}$ of the polysaccharide and $0.375 \mathrm{mg}$ of the lytic enzyme, $0.848 \mathrm{mg}$ of $\beta-1,3$-glucanase or $1.18 \mathrm{mg}$ of $\beta$-1,6-glucanase in $4.0 \mathrm{ml}$ of $\mathrm{M} / 20$ acetate buffer, $\mathrm{pH}$ 5.5 , were incubated at $40^{\circ} \mathrm{C}$. After $2 \mathrm{hr}$ incubation the mixtures were heated and chromatographed. Identification of the sugar spots was done following the French and Wild's method. ${ }^{70)} \mathrm{A}$, Control; B, incubated with the lytic enzyme; $C$, incubated with

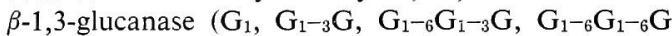
or $\left.\mathrm{G}_{1-3} \mathrm{G}_{1-3} \mathrm{G}_{1-6} \mathrm{G}\right) ; \mathrm{D}$, incubated with $\beta$-1,6-glucanase $\left(\mathrm{G}_{1}, \mathrm{G}_{1-3} \mathrm{G}, \mathrm{G}_{1}-\mathrm{G}_{6}, \mathrm{G}_{1-{ }_{3}} \mathrm{G}_{1-3} \mathrm{G}_{1-3} \mathrm{G}, \mathrm{G}_{1-{ }_{6}} \mathrm{G}_{1-{ }_{6}} \mathrm{G}\right.$ or $\left.\mathrm{G}_{1-3} \mathrm{G}_{1-3} \mathrm{G}_{1-} \mathrm{G}\right)$; $\mathrm{E}$, laminari oligosaccharides; $F$, glucose and gentiobiose.

A series of laminari oligosaccharides ranging from $G_{3}$ to $G_{8}$ was tested for substrate for lytic enzyme, but none of them was digested.

Action on living yeast. In a previous paper the lytic activity of the enzyme on $S$. cerevisiae LK2 G12 was studied, but its activity on the other yeasts remained to be studied. Table III shows susceptibility of yeasts to the enzyme.

Immunological studies of the lytic enzyme. Serological differentiation among some yeast
Table III. Susceptibility of Yeasts to the Crystalline Enzyme

\begin{tabular}{|c|c|c|}
\hline & \multicolumn{2}{|c|}{ Relative rate of lysis ${ }^{a}$ l } \\
\hline & $\begin{array}{l}\text { Log-phase } \\
\text { cells }\end{array}$ & $\begin{array}{l}\text { Stationary- } \\
\text { phase cells }\end{array}$ \\
\hline Candida utilis IFO 0396 & 67 & 15 \\
\hline albicans IFO 0197 & $\mathbf{0}$ & 0 \\
\hline macedoniensis IFO 0706 & 50 & 25 \\
\hline pseudotropicalis IFO 0617 & 80 & 75 \\
\hline krusei IFO 0013 & 50 & 85 \\
\hline guilliermondii IFO 0566 & 93 & 100 \\
\hline Cryptococcus laurentii IFO 0609 & $\mathbf{0}$ & 20 \\
\hline Endomyces hordei IFO 0104 & 0 & 0 \\
\hline Hansenura Jadini IFO 0987 & 25 & 20 \\
\hline octospora IFO 0145 & 60 & 40 \\
\hline bimundalis IFO 1366 & 50 & 40 \\
\hline \multicolumn{3}{|l|}{ Kluyveromyces polysporus } \\
\hline IFO 0996 & 75 & 60 \\
\hline Kloekera apiculata IFO 0154 & 70 & 27 \\
\hline Pichia polymorpha IFO 0195 & 33 & 28 \\
\hline Saccharomyces ellipsoideus & 10 & 20 \\
\hline delbrueckii IFO 0285 & 86 & 38 \\
\hline cerevisiae & 80 & 75 \\
\hline carlsbergensis IFO 0641 & 104 & 102 \\
\hline oviformis IFO 0262 & 91 & 83 \\
\hline cerevisiae LK2 G12 & 100 & 20 \\
\hline \multicolumn{3}{|l|}{ Sporobolomyces salmonicolor } \\
\hline IFO 0374 & 0 & 0 \\
\hline Torulopsis candida IFO 0768 & 0 & 0 \\
\hline Tricosporon cutaneum IFO 0174 & 0 & 0 \\
\hline margaritiferum IFO 1208 & 0 & 0 \\
\hline
\end{tabular}

a) The assay was conducted, using $10 \mu \mathrm{g} /$ tube of enzyme, under the standard assay conditions, and the susceptibility of $S$. cerevisiae LK2 G12 was assigned to 100 . Under these conditions nearly complete disruption was obtained for $S$. cerevisiae LK2 G12 ( $\Delta$ O.D. at $610 \mathrm{~nm}=0.25$ ).

cell lytic enzymes, such as present lytic enzyme, lytic enzyme from a Fungi Imperfecti, ${ }^{40,411}$ crude lytic enzyme from Flavobacterium dormitator var. glucanolyticae ${ }^{43)}$ and snail gut juice, using Ouchterlony's immunodiffusion tests was attempted. A clear band appeared only between the antiserum and the present lytic enzyme (antigen).

\section{DISCUSSION}

From the cultural characteristics of the organism, especially maximum growth temperature, it was considered to belong in the 
Chinensis section of the genus Rhizopus. In this section two species, Rhizopus chinensis and Rhizopus pseudochinensis, are included; they are distinguished from each other only by the Voges-Proskauer test. The suspended organism was negative for the test and, hence, identified as Rhizopus chinensis. The morphological, cultural and physiological characteristics of the organism were the same as those of Rhizopus chinensis IFO 1078, which was used as a reference organism, except the ability to form yeast cell-lytic enzyme. Therefore it has been designated as Rhizopus chinensis R-69.

From a culture filtrate of the strain a kind of endo $\beta$-1,3-glucanase which lyses the cells of living yeast (or forms protoplasts from $\log$ phase yeast) was crystallized. The enzyme was homogeneous according to various criteria and its molecular weight, tentatively given as 19,000 in a previous paper, ${ }^{36)}$ was determined to be $22,000-24,000$ by the various means described above.

The enzyme has been separated from $\beta-1,3-$ glucanase and $\beta-1,6$-glucanase according to the criteria of the DNSA method, but it is still active on yeast glucan consisting of $\beta-1,3-$ and $\beta$-1,6-glucosidic linkages. The data given in Fig. 7 show that the glucanolytic activity and the living yeast cell lytic activity originate from the same enzyme protein. In a previous paper the enzyme was supposed to be $\beta$-glucanase of a debranching type, inasmuch as it liberated from yeast glucan the oligosaccharides which correspond in degree of polymerization to side chains of the yeast glucan. An attempt to prove the disappearance of the branching point from laminarin and yeast glucan to be a result of enzyme action by methylation analysis combined with gas liquid chromatography was unsuccessful because of the difficulty of methylation. As stated in "RESULTS" in this paper, laminarin which contains linear $\beta$-1,3-linked chains of D-glucose units with occasional $\beta-1,6$ links has not been depolymerized by the enzyme to a readily distinguishable extent. On the other hand, yeast glucan, which is a highly polymerized and branched $\beta-1,3$-glucan containing significant amount of $\beta$-1,6-glucosidic linkage, was cleaved rapidly by the enzyme, releasing high molecular weight carbohydrate and a comparatively little amount of reducing sugar. These observations suggest that the enzyme is more specific for yeast glucan than for laminarin. Considering the difference in the structural features of yeast glucan and laminarin, the action of the enzyme seems to be related to branching points; however, that the enzyme may be a "more random" type of glucanase, such as the $C_{1}$ component of cellulase, also seems reasonable, inasmuch as the increase in reducing sugars in Fig. 8 may be attributed to the second order cleavage of released carbohydrate.

Recently Doi et $a l^{39 /}$ have reported the presence of "laminaripentaose cut out type" glucanase in an Arthrobacter bacteria. Our enzyme reported here differs from their glucanase in its mode of action on yeast glucan, especially at the initial stage of the reaction, and also from the "more random" type glucanase of Fungi Imperfecti reported previous$1 y^{40,41)}$ in its mode of action on laminarin. However, as the accurate bond split by the enzyme could not be identified within the scope of this paper, our next paper will focus on that subject.

\section{REFERENCES}

1) M. R. J. Salton, J. Gen. Microbiol., 12, 25 (1955).

2) K. Horikoshi and K. Sakaguchi, J. Gen. Appl. Microbiol., 4, 1 (1958).

3) K. Horikoshi and S. Iida, Nature, 181, 917 (1958).

4) K. Horikoshi and S. Iida, ibid., 183, 186 (1959).

5) A. Furuya and Y. Ikeda, J. Gen. Microbiol., 6, 40 (1960).

6) A. Furuya and Y.Ikeda, Nippon Nogeikagaku Kaishi, 34, 33 (1960).

7) A. Furuya and Y. Ikeda, ibid., 34, 38 (1960).

8) Y. Satomura, M. Ono and J. Fukumoto, Bull. Agr. Chem. Soc. Japan, 34, 652 (1960); idem, ibid., 24, 317 (1960).

9) K. Takayama, K. Udagawa and S. Abe, Nippon Nôgeikagaku Kaishi, 34, 652 (1960); idem, ibid., 34, 656 (1960).

10) Y. Satomura, S. Oi and M. Ono, Agr. Biol. Chem., 25, 19 (1961).

11) C. Garcia-Mendoza and J. R. Villanueva, Microbiol. Espan., 15, 139 (1962); idem, Nature, 195, 
1326 (1962); idem, Can. J. Microbiol., 9, 141 (1963).

12) I. G. Acha and J. R. Villanueva, Nature, 200, 1231 (1963).

13) J. Ebata and Y. Satomura, Agr. Biol. Chem., 27, 471 (1963); idem, ibid., 27, 478 (1963).

14) S. Gascon and J. R. Villanueva, Can. J. Microbiol., 9, 651 (1963); idem, ibid., 10, 301 (1964); idem, Nature, 205, 822 (1965).

15) R. Mitchell and M. Alexander, J. Microbiol., 8, 167 (1963); idem, ibid., 8, 172 (1963).

16) S. Tabata and G. Terui, J. Ferment. Technol., 41, 390 (1963); idem, ibid., 43, 777 (1965).

17) S. Gascon, A. G. Ochoa and J. R. Villanueva, Can. J. Microbiol., 11, 573 (1965).

18) S. Gascon, A. G. Ochoa, M. Novas and J. R. Villanueva, Arch. Mikrobiol., 51, 156 (1965).

19) H. Tanaka and H. J. Phaff, J. Bacteriol., 89, 1570 (1965).

20) K. Yasumatsu, M. Ohno, M. Tobari and H. Shimazono, J. Ferment. Technol., 44, 847 (1966).

21) H. Sugimoto, Agr. Biol. Chem., 31, 1111 (1967); idem, Rept. Noda. Sci. Res., 12, 40 (1968); idem, ibid., 12, 53 (1968); H. Sugimoto and T. Yokotsuka, J. Ferment. Technol., 46, 513 (1968).

22) A. Kuroda, Y. Tokumaru and N. Tawada, $J$. Ferment. Technol., 46, 926 (1968); A. Kuroda, N. Tawada and Y. Tokumaru, ibid, 46, 930(1968).

23) N. Toyama and K. Ogawa, J. Ferment. Technol., 46, 626 (1968).

24) M. Kawai, ibid., 48, 295 (1970); idem, ibid., 48, 397 (1970)

25) T. Sawasaki and H. Shimokawa, Agr. Biol. Chem., 34, 243 (1970).

26) S. Nagasaki, P. N. Neumann, P. Arnow, L. D. Schnable and J. O. Lampen, Biochem. Biophys. Res. Comm., 25, 158 (1966).

27) W. L. McLellan Jr., and J. O. Lampen, J. Bacteriol., 95, 967 (1968).

28) S. Nagasaki and S. Yamamoto, Res. Rept. Kochi Univ., Agr. Sci, 17, 93 (1968).

29) W. L. McLellan Jr., L. E. McDaniel and J. O. Lampen, J. Bacteriol., 102, 261 (1970).

30) J. Monreal, F. De Uruburu and J. R. Villanueva, J. Bacteriol., 94, 241 (1967)

31) R. E. Domanski and R. E. Miller, ibid., 96, 270 (1968).

32) K. Doi and T. Fukui, J. Biochem., 70, 711 (1971).

33) K. Kitamura, T. Kaneko and Y. Yamamoto, Arch. Biochem. Biophys., 145, 402 (1971).

34) M. Mada, K. Hirao, Y. Kimura and K. Noda, Nippon Nogeikagaku Kaishi, 44, 393 (1970); idem, ibid., 45, 260 (1971); idem, ibid., 45, 269 (1971).

35) S. Yamamoto and S. Nagasaki, Abstracts of Papers, 4th International Fermentation Symposium, Kyoto, March, 1972, p. 295.

36) S. Yamamoto, T. Shiraishi and S. Nagasaki, Biochem. Biophys. Res. Commun., 46, 1802 (1972).
37) K. Kitamura, K. Kaneko and Y. Yamamoto, Abstracts of Papers, 4th International Fermentation Symposium, Kyoto, March 1972, p. 294.

38) J. D. Macmillan and J. W. Mann, Abstracts of Papers, 4th International Fermentation Symposium, Kyoto March, 1972, p. 252.

39) K. Doi, A. Doi and T. Fukui, Agr. Biol. Chem., 37, 1619 (1973); idem, ibid., 37, 1629 (1973).

40) S. Yamamoto, J. Fukuyama and S. Nagasaki, Agr. Biol. Chem., 38, 329 (1974).

41) S. Nagasaki, J. Fukuyama, S. Yamamoto and R. Kobayashi, Agr. Biol. Chem., 38, 349 (1974).

42) T. Inui, Y. Takeda and H. lizuka, Gen. Appl. Microbiol., 11,

43) S. Yamamoto and S. Nagasaki, J. Ferment. Technol., 50, 117 (1972).

44) B. J. Davis, Ann. New York Acad. Sci., 121, Art. 2, 404 (1964).

45) L. Ornstein, ibid., 121, Art. 2, 321 (1964).

46) K. Weber and M. Osborn, J. Biol. Chem., 244, 4406 (1969).

47) E. Scoffen, A. Fontana and R. Rochi, Biochemistry, 7, 971 (1968).

48) T. W. Goodwin and R. A. Morton, Biochem. J., 40, 628 (1946).

49) A. M. Crestfield, S. Moore and W. H. Stein, $J$. Biol. Chem., 238, 622 (1963).

50) S. Moore, R. D. Cole, H. G. Gundlach and W. H. Stein, Symposium on Proteins, 4th International Congress of Biochemistry, Vienna, 1958.

51) E. Steers, Jr., G. R. Craven and C. B. Antinsen, J. Biol. Chem., 240, 2478 (1965).

52) H. Matsubara and F. M. Sasaki, Biochem. Biophys. Res. Commun., 35, 175 (1969).

53) F. Sanger, Biochem. J., 39, 507 (1945).

54) S. Erikson and J. Sjöquist, Biochem. Biophys. Acta, 45, 290 (1960).

55) W. R. Gray and B. S. Hartley, Biochem. J., 89, 59 p (1963).

56) A. L. Levy, Nature, 174, 126 (1954).

57) J. Sjöquist, Biochem. Biophys. Acta, 41, 20 (1960).

58) A. A. Boulton and I. E. Bush, Biochem. J., 92, $11 \mathrm{p}$ (1964).

59) S. Akabori, K. Ohno, T. Ikenaka, Y. Okada, H. Hanafusa, A. Tsugita, K. Suga and T. Matsushima, Bull. Chem. Soc. Japan, 29, 507 (1956).

60) J. H. Bradbury, Biochem. J., 68, 475 (1958); idem, ibid., 68, 482 (1958).

61) H. Fraenkel-Conrat, J. L. Haris and A. Levy, "Methods in Biochemical Analysis," Vol. II, ed. by D. Glick, Interscience, 1955 , p. 397.

62) S. J. Edelstein and H. K. Schachman, J. Biol. Chem., 242, 306 (1967).

63) T. L. McMeekin and K. Marshall, Science, 116, 142 (1952).

64) K. E. Van Hold and R. L. Baldwin, J. Phy. Chem., 62, 734 (1958). 
65) Miller and Golder, Arch. Biochem., 29, 420 (1950).

66) G. K. Ackers, J. Biol. Chem., 242, 3237 (1967).

67) H. A. Scheraga and L. Manderkern, J. Am. Chem. Soc., 75, 179 (1953).

68) H. A. Scheraga, J. Chem. Phys., 23, 1526 (1955).

69) W. Kuhn and H. Kuhn, quated in "Seibutsu Butsurigaku Koza," Vol. 5, ed. by Nippon Sei- butsu Butsuri Gakkai, Yoshioka Shoten, Kyoto, 1966 , p. 310.

70) D. French and G. M. Wild, J. Am. Chem. Soc., 75, 2612 (1953).

71) A. Misaki, J. Johnson, S. Kirkwood, J. V. Scaletti and F. Smith, Carbohydrate Res., 6, 150 (1968). 